ISBN 978-81-933894-1-6

2017 International Conference on Studies in Business Management, Law and Education

(SBMLE-17)

Kyoto (Japan) April 20-21, 2017

\title{
A New Conceptual Framework to Examine Sustainability Issues in Project Environments
}

\author{
Zeinab Sazvar ${ }^{1}$,Seyed Hossein Iranmanesh ${ }^{2}$, Rahim Nikandish ${ }^{3}$, Mohsen Safaei ${ }^{4}$ \\ ${ }^{1}$ Assistant Professor, Industrial Engineering Department, College of Engineering, University of Tehran, Iran \\ ${ }^{2}$ Associate Professor, Industrial Engineering Department, College of Engineering, University of Tehran, Iran \\ ${ }^{3,4}$ Master student, Industrial Engineering Department, College of Engineering, University of Tehran, Iran
}

\begin{abstract}
In the present study, the attempt is made to investigate the sustainability in project management as the novel applied and research topic. To this end, a variety of scientific research performed in this regard were gathered. These studies were mostly focused on the investigation of sustainability in project and project management, the relation between them, and the practical implementation of the sustainability indicators. The aforementioned matters were primarily dealt in a qualitative way by using questionnaire and checklists as the main research tools. The views and findings of the most notable works reviewed in this subject area are classified into two general categories of qualitative and quantitative studies. Finally, the potential areas were identified and classified into seven general groups including: 1. Sustainability Indicators 2. Project levels 3. Case studies 4. NGOs 5. Project manager 6.project management standards and 7- Using quantitative models and mathematical tools.
\end{abstract}

Keywords: project management, sustainable, sustainability in project management, project manager and sustainable development.

\section{Introduction}

In today's world, contrary to the past, the succeeding generations are deemed to have their own share of the world. Indeed, we are not allowed to jeopardize the life of the following generations to provide a better life for ourselves. Endangering their life has various aspects among which the surrounding environment is maybe the first one comes to the mind [1].

In fact, such a perspective towards the next generations can be extended to the concept of sustainability, that is to say, we have to follow the principles of the sustainability in performing activities. Accordingly, one of the main challenges leadership currently face in business is to integrate it into the main functions of the business. The development of sustainability has shifted from the pivotal concern of the pressure groups including organizations supporting the environment and society to the vital concern of business managers. For these managers, the central concern is to practically implement sustainability in their business. Sustainability fails to mean following the existing business practices but rather rethinking, redesigning, and redeveloping the business practices in a sustainable manner.

One of the functions of the business is project management. In the current project management methods, such a process is overshadowed by the "'triple constraint", i.e. quality, cost, and time. The foregone aspects firmly emphasize the economic benefit. Even though, social and environmental aspects may, in some cases, be considered the aspects of quality, they have been hardly investigated or applied directly and independently.[2] 
Therefore, the relation between sustainability and project management is assumed to be an emerging field of study about which there is limited academic research. Sustainability in project management is about integrating economic, social and environmental aspects into the management systems, formats, and project governance.

Evidence of project failure in the industry sphere suggests the necessity of further investigations of the sustainable development.[3] In other words, experience indicates that senior management in project-based organizations (PBO) may, at times, tend to follow and to include sustainability considerations in the project management; however, they may fail to know which measures and metrics they may require to this end.[4]

The study is organized as follows: section two presents a review of selected literature in the area of sustainable project management. Section three describes the existing research gap in this regard, followed by recommendation of potential areas for the future research. And finally, concluding remarks are presented in section four.

\section{Literature of past works}

Because of the novelty of the subject and its rapid growth, the majority of selected papers are belonging to the second decade of the twenty-first century. selected articles are found using the following keywords: "project management", "sustainable", "sustainability in project management", "project manager" and "integrating sustainability and project management". The aforementioned matters were primarily dealt in a qualitative way by using questionnaire and checklists as the main research tools. The chosen articles from different parts of the world investigate both theoretical and practical aspects. The views and findings of the most notable works reviewed in this subject area are classified into two general categories of qualitative and quantitative studies.

\section{TABLE 1: Qualitative Studies About Sustainability in Project Management}

Author/Date

Silivius et al

(2010) [5]

Fernández-

Sánchez

Rodríguez-López

(2010) [6]

Talbot

\&Venkataraman

(2011)[7]

(

Craddock

(2013)[8]

\begin{tabular}{|l} 
\\
\hline Gareis (2013)[9]
\end{tabular}

(2013) [9]

Tharp (2013)[10]

\section{Study Purpose}

to give a maturity model for the integration of sustainability in projects and project management processes.

to identify, sort and prioritize

\& sustainability indicators based on risk management standards

to suggest a structure for merging sustainability into project baselines for consulting engineering projects

\section{Relevant Findings}

providing a comprehensive overview of the concepts of sustainability and their application to project management

Sustainability in project management develops the system boundaries of the project and of project management

developing a methodology for choosing sustainability indicators by all stakeholders

- $\quad$ applying the methodology in a research project in an effort to identify indicators for linear infrastructure projects in Spain

to make a practicable model for the assessment of sustainability

providing determinable indicators in a project setting

distinguishing the sustainability sub-indicator's possessor who could be responsible for its attainment

applying the high level sustainability indicators to regiment the gathered stakeholder requirements into sustainability issues

to create the linkages among

Business Excellence Models, project sustainability, and project success

to seek how sustainability can be considered while managing the transformation of a project

to examine aspects of a sustainable project and feasible implementation guidelines them to integration sustainability into the project processes applying Business Excellence models in a project environment

- preparing a framework to direct sustainability in an organization by BEMs

- $\quad$ Putting upon BEMs to address project sustainability as one contributor to project success

changing project dimensions in transforming process

can be considering the principles of sustainable development in changes of projects

sustainability might cause and be a reason the transformation of a project

perceiving the risk of relinquishing sustainability aspects in both short-term and long-term impacts in a project management knowledge areas

- $\quad$ interpreting the basic sustainability aspects to the corporate setting and the broader society investigating how to incorporate sustainability ways into project 


\begin{tabular}{|c|c|c|}
\hline $\begin{array}{l}\text { Brent\&Carin } \\
(2013)[11]\end{array}$ & $\begin{array}{l}\text { to study how sustainability } \\
\text { could be addressed in the project } \\
\text { management, based on the } \\
\text { resolution of four pragmatic } \\
\text { instances }\end{array}$ & $\begin{array}{l}\text { - accentuating the risk of diminishing all sustainability aspects of a } \\
\text { project to one common denominator that can be more unmistakable to } \\
\text { decision-makers } \\
\text { presenting a system dynamics approach to the sustainability valuation } \\
\text { of renewable energy Project developments }\end{array}$ \\
\hline $\begin{array}{l}\text { Tufinio et al } \\
(2013)[12]\end{array}$ & $\begin{array}{l}\text { to assess the common scenario } \\
\text { of sustainability implementation } \\
\text { in projects and project } \\
\text { management practice }\end{array}$ & $\begin{array}{l}\text { - } \quad \text { Drivers for sustainability implementation can be from different causes } \\
\text { - } \quad \text { The sustainability roadmap is not similar for each organization. }\end{array}$ \\
\hline $\begin{array}{l}\text { Maltzman\& } \\
\text { Shirley, (2013)[13] }\end{array}$ & $\begin{array}{l}\text { to show the importance of the } \\
\text { role of the project manager in } \\
\text { attaining organizational } \\
\text { sustainability in an enterprise }\end{array}$ & $\begin{array}{l}\text { - directing the paths in which the project manager can entreat the role as } \\
\text { change representative on their projects and within their corporate } \\
\text { the emphasis on developing a new mindset, a new framework of } \\
\text { reversion }\end{array}$ \\
\hline Winnall(2013)[14] & $\begin{array}{l}\text { to illustrate how the alliance of } \\
\text { social risk monitoring can } \\
\text { essentially go forward the } \\
\text { probability of a project's } \\
\text { success }\end{array}$ & 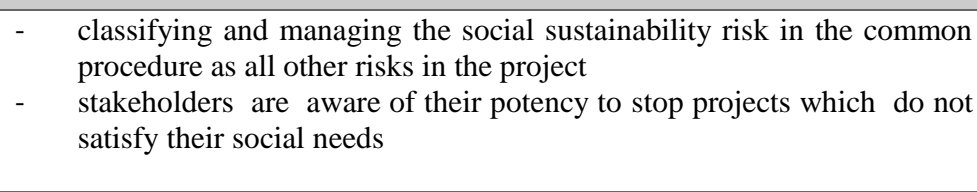 \\
\hline $\begin{array}{l}\text { Schipper, } \\
\text { \&Nedeski } \\
(2013)[15]\end{array}$ & $\begin{array}{l}\text { to perceive the major subjects } \\
\text { with the practical application of } \\
\text { sustainability to a real project, } \\
\text { and to render a method for } \\
\text { analysis }\end{array}$ & $\begin{array}{l}\text { - finding } 8 \text { contraptions which could supply to an utmost sustainable } \\
\text { contribution } \\
\text { raising a manifest difference between the internal project viewpoint of } \\
\text { sustainability and external viewpoint of sustainability }\end{array}$ \\
\hline $\begin{array}{l}\text { Goedknegt } \\
(2013)[16]\end{array}$ & $\begin{array}{l}\text { to display what a project } \\
\text { manager can play a role in the } \\
\text { implementation of sustainability } \\
\text { within the project and the } \\
\text { management process }\end{array}$ & $\begin{array}{l}\text { - the sustainability degree on a project is dependent on the project } \\
\text { manager's priorities } \\
\text { the project manager has a medium accountability for considering the } \\
\text { holistic approach and the long-term view in sustainability project } \\
\text { management }\end{array}$ \\
\hline Eid (2013)[17] & $\begin{array}{l}\text { to describe and to explore the } \\
\text { suggestion of a tri-dimensional } \\
\text { coalition between construction, } \\
\text { sustainable development , and } \\
\text { project management }\end{array}$ & $\begin{array}{l}\text { - examining the relationship between sustainable development and } \\
\text { project management through its application in a construction project } \\
\text { nominating and evaluating the eligible change of sustainable } \\
\text { development guidelines into the project management standards }\end{array}$ \\
\hline $\begin{array}{l}\text { Wang et al } \\
\text { (2015) }[18]\end{array}$ & $\begin{array}{l}\text { to determine vital factors for } \\
\text { sustainable } \\
\text { project management }\end{array}$ & $\begin{array}{l}\text { - leadership, process control and communication are the most important } \\
\text { factor in the sustainability project management } \\
\text { - } \quad \text { team management and innovation are the least important factors }\end{array}$ \\
\hline $\begin{array}{l}\text { Marcelino-Sádaba } \\
\text { et al (2015) [19] }\end{array}$ & $\begin{array}{l}\text { to dissect connections between } \\
\text { sustainability and project } \\
\text { management via a } \\
\text { comprehensive literature review }\end{array}$ & $\begin{array}{l}\text { defining an original conceptual framework to manage sustainable } \\
\text { projects, based on four dimensions: products, processes, organizations } \\
\text { and managers }\end{array}$ \\
\hline $\begin{array}{l}\text { Martens } \\
\& \text { Carvalho (2016) } \\
{[20]}\end{array}$ & $\begin{array}{l}\text { to recognize major variables of } \\
\text { sustainability in project } \\
\text { management context and }\end{array}$ & 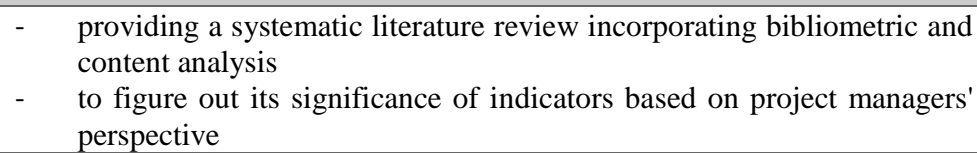 \\
\hline
\end{tabular}

As it is observed in Table 2, in recent years there has been a wave of studies dealing with the indicators of sustainability in project management using mathematical modeling as well as multi-objective/multi-criteria decision-making tools.

TABLE 2: Quantitative Studies About Sustainability in Project Management

Author/Date

Shen et al (2007) [21]

Khalili-

Damghani\&SSadi-

Nezhad (2013)

[22]

Heravi et al

(2015) [23]
Study Purpose

Relevant Findings

to engender a checklist for evaluating project sustainability performance across its life cycle

to establish a decision support

system to untangle sustainable project selection problem

to determine and evaluate sustainability indicators for three allowing all project parties to determine the project sustainability performance in a constant and comprehensive way amending the collaboration among all stakeholders to achieve adequate project sustainability performance facilitating perception the primary factors impressing a project sustainability performance across its life cycle considering simultaneously the maximum precision and minimum complexity by the proposed framework using decision support system in a real case of sustainable project selection.

identifying and evaluating the main sustainability indicators through
petrochemical projects life-cycle 


\begin{tabular}{|l|l|ll|}
\hline & phases petrochemical projects & - & $\begin{array}{l}\text { the environmental dimension is of great importance to operation and } \\
\text { maintenance phase } \\
\text { the most momentous dimension in the construction phase is the } \\
\text { economic dimension }\end{array}$ \\
\hline $\begin{array}{l}\text { Sánchez } \\
(2015)[24]\end{array}$ & $\begin{array}{l}\text { to develop a framework to } \\
\text { avouch a true portfolio selection } \\
\text { to gain business strategy and } \\
\text { stakeholders demands }\end{array}$ & $\begin{array}{l}\text { accomplishing a simultaneous analysis of eco-impacts to } \\
\text { organizational objectives } \\
\text { evaluating sustainability for portfolio selection and project monitoring } \\
\text { formularizing the portfolio selection and project monitoring problems } \\
\text { methodically }\end{array}$ \\
\hline $\begin{array}{l}\text { hen et al. } \\
(2016)[25]\end{array}$ & $\begin{array}{l}\text { to assay the effects of the share } \\
\text { repartition between public and } \\
\text { private segments on project } \\
\text { sustainability performance }\end{array}$ & - & $\begin{array}{l}\text { getting an expected level of sustainability performance by organizing } \\
\text { appropriate investment distributions between the two sectors in a } \\
\text { public-private-partnership project } \\
\text { putting out a noteworthy system for defining investment distributions } \\
\text { in a PPP-type project towards higher project sustainability } \\
\text { performance. }\end{array}$ \\
\hline $\begin{array}{l}\text { Siew et al } \\
(2016)[26]\end{array}$ & $\begin{array}{l}\text { to appraise project sustainability } \\
\text { in a progressive manner via } \\
\text { maturity levels }\end{array}$ & - & $\begin{array}{l}\text { presenting sustainability maturity model relating to main project } \\
\text { activities } \\
\text { considering uncertainty in the assessment of project sustainability } \\
\text { maturity levels }\end{array}$ \\
\hline $\begin{array}{l}\text { Martens et al } \\
(2016) \text { [27] }\end{array}$ & $\begin{array}{l}\text { to identify key variables of } \\
\text { sustainability in project } \\
\text { management, and to explore the } \\
\text { impact of these variables on } \\
\text { project success }\end{array}$ & $\begin{array}{l}\text { develop a framework incorporating sustainability in project } \\
\text { management and project success } \\
\text { giving more importance to sustainability in projects by project } \\
\text { managers }\end{array}$ \\
\hline
\end{tabular}

\section{Potential for Future Research}

The reviewed literature reveals a significant relation between sustainability in projects and project management. Moreover, regarding the role of project manager, scholars appears to agree that the aforementioned role is crucial in including sustainability in projects; however, the project manager is officially responsible for a number of project's aspects.

By studying the previous papers and their results, it can be concluded that the key to success in implementing sustainability is establishing a proper and strong relation between project and project management. However, sometimes other subjects could be linked to such a relation, the before-mentioned proper and strong relation between projects and projects management is the main element for establishing sustainability.

In relation to sustainability, a plethora of indicators could be studied. Table. 3 lists the most important ones. But the question is that whether these indicators are the same for all projects? The response is, No, for each project, irrespective of the place where it is done, has its own requirements. As the present study is focused on three main domains of economic, social, and environmental usefulness, these indicators could be changed according to the place where the project is being conducted [28]. For instance, social indicators have extensively high importance in African countries rather than the wealthiest European countries where environmental indicators have higher significance.

TABLE 3: Main Indicators of Sustainability in Project Management

\begin{tabular}{ll}
\hline Economic Indicator & return on investment, business agility \\
\hline Environmental Indicator & transport, energy, waste, water, material \\
\hline Social Indicator & Human rights, society and customers, labor practices and decent work, ethical behavior \\
\hline
\end{tabular}

Due to the reasons mentioned above, further use of case studies may help us in this regard. Put it another way, the more the considered case studies, the better the conclusions in sustainability area; consequently, all indicators and their impacts could be well scrutinized. However, as this is an emerging topic, more time is required to see the impacts of such indicators.

According to what mentioned in literature review section, potential areas for future research could be presented in seven general groups.

1. Corporate Social Responsibility (CSR) requirements: In addition to the indicators mentioned in previous papers, there are other options, whether to add further indicators or to combine ones mentioned in the literature. Furthermore, some indicators could be considered with more details. Establishing green jobs 
(i.e. environmentally friendly jobs) through implementing projects, is one of the indicators having received less attention in the previous studies.

2. Project levels: In a number of studies, this very subject has been examined in a special level of the project. For example, in some projects, the main emphasis has been focused on starting a project; while others have separately examined this matter in different phases of the project from design to implementation or even failure. Seamless examination of this matter at different levels of the project and determination of the relative significance of these levels from the facet of sustainability are the other potential areas for further research.

3. Case studies: As the previous studies indicated, diverse case studies may lead to different results. New studies could be provided by investigating this matter, particularly in mega projects including infrastructure projects and oil and gas projects of the country, as well as localizing the sustainability indicators.

4. Project manager: It is an open secret that project manager could enact a crucial role in project management. Therefore, the project manager could be particularly considered the main focus to investigate the sustainability in projects and project management. Project managers would have to accept more responsibility for the sustainable future. Determining the effects of capabilities, points of view, skills, and different levels of managers' knowledge as well as the effectiveness level of each factor in various case studies, is another novel area in the sustainability project management.

5. NGOs: Sustainability generally constitutes three main aspects; while projects continuously deal with the economic indicators, when sustainability is concerned, the environment and society receive the most emphasis. As it is known to all, NGOs rarely take into account the economic indicator; thus focusing on them may reveal the impacts of social and environmental indicators on the success of the business as well as the way economic indicators affect the other ones.

6. Project management standards: Each project could be evaluated by various standards. However, most of the articles have used PMBOK guide and standards. The standards used for project management, consider sustainability either partial or implicit.[29] In fact, one of the criticisms presented in the recently published PMBOK guide (v.5)for the project management knowledge is that the relation between sustainable development and project management has failed to be properly investigated. One of the rational reasons for such a shortcoming is a lack of sufficiently developed understanding of the impact of sustainability on the project management principles, concepts, and processes. Other project management standards such as APM, PRINCE2, ICB and ISO 10006 could also be considered from the perspective of sustainability. Establishing and improving standards by taking into account the concepts of sustainability could definitely provide a great help to develop and implement these concepts in the projects.

7. Quantitative models and mathematical tools: As it was found in literature review section, most studies in this area are qualitative. In recent years, using mathematic models and tools, as well as multiobjective/multi-criteria decision-making models as the novel tools have drawn the attention of researchers. 


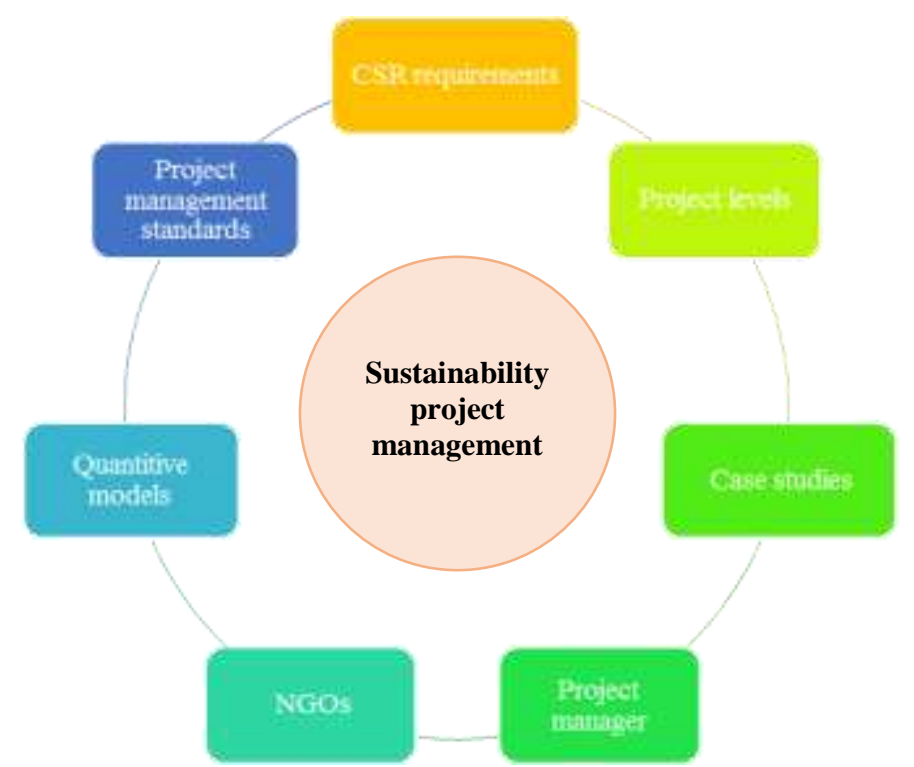

Fig. 1: Potential Areas in Sustainability Project Management for Future Research

\section{Conclusion remarks}

The present study aimed at presenting an overview of the views and findings of the relation between sustainability and project management. Studies developed in recent years were considered in two qualitative and quantitative groups. Afterwards, the potential areas were identified and classified into seven general groups.

In short, there are two main directions for future researches. Firstly, they could investigate the new concepts in this relation, integrate different subjects, and use more comprehensive standards in this regard. Secondly, they could quantify these indicators by using new models and look at the matter more realistically by using multiplecriteria evaluation models.

In this study, the attempt was made firstly to enlighten students and academic researchers as to the studied issue and to inspire them to carry out further studies on projects sustainability, and secondly to improve the knowledge and intuition of industrial and academic advisors, project sponsors, project managers, and project team to well understand the implementation of sustainability in the projects and incorporation of sustainability practices in the project management as well.

\section{Acknowledgements}

Please acknowledge collaborators or anyone who has helped with the paper at the end of the text.

\section{References}

[1] BSR/GlobeScan State of Sustainable Business Survey, 2015.

[2] Barnard, L. T., B. Ackles, and J. L. Haner. "Making sense of sustainability project management." ExplorusGroup Inc, 2011.

[3] Oehlmann, Iris, The Sustainable Footprint Methodology, Including sustainability inthe project management of the Bergermeer Gas Storage project, 2012.

[4] Silvius, Gilbert, Ron Schipper, and Julia Planko. Sustainability in project management. Gower Publishing, Ltd., 2012.

[5] Silvius, AJ Gilbert, and Ron Schipper. "A maturity model for integrating sustainability in projects and project management." 24th World Congress of the International Project Management Association. IPMA Istanbul, 2010.

[6] Fernández-Sánchez G \& Rodríguez-López F, A methodology to identify sustainabilityindicators in construction project management-Application to infrastructure projectsin Spain, 2010, Ecological Indicators, 10.6 1193-1201.

[7] J. Talbot and R. Venkataraman, "Evaluating Sustainability on Projects Using Indicators," Sustainability Integration for Effective Project Management, p. 194, 2013.

https://doi.org/10.4018/978-1-4666-4177-8.ch012 
[8] W. T. Craddock, "How Business Excellence Models Contribute to Project Sustainability and Project Success," Sustainability Integration for Effective Project Management, pp. 1-19, 2013.

https://doi.org/10.4018/978-1-4666-4177-8.ch001

[9] R. Gareis, "Changes of Projects by Considering the Principles of Sustainable Development Case Study: Transforming the Project Hospital North," Sustainability Integration for Effective Project Management, p. 304, 2013.

https://doi.org/10.4018/978-1-4666-4177-8.ch019

[10] J. Tharp, "Sustainability in Project Management: Practical Applications," Sustainability Integration for Effective Project Management, p. 182, 2013

https://doi.org/10.4018/978-1-4666-4177-8.ch011.

[11] L. Crawford, "Leading Sustainability through Projects," Sustainability Integration for Effective Project Management, pp. 235-244, 2013. https://doi.org/10.4018/978-1-4666-4177-8.ch014

[12] Tufinio, SilvanaPaniagua, et al. "SUSTAINABILITY IN PROJECT MANAGEMENT: WHERE ARE WE?." Annals of the Faculty of Engineering Hunedoara 11.1, 2013, p. 91.

[13] Maltzman and D. Shirley, "Project Manager as a Pivot Point for Implementing Sustainability in an Enterprise," Sustainability Integration for Effective Project Management, pp. 262-278, 2013.

[14] J.-L. Winnall, "Social Sustainability to Social Benefit: Creating Positive Outcomes through a Social Risk-based approach," Sustainability Integration for Effective Project Management, pp. 95-105, 2013. https://doi.org/10.4018/978-1-4666-4177-8.ch006

[15] R. Schipper and S. Nedeski, "Application of Sustainability Considerations in Practice: The Open Remote Case," Sustainability Integration for Effective Project Management, p. 337, 2013.

https://doi.org/10.4018/978-1-4666-4177-8.ch021

[16] Goedknegt, Debby. "Sustainability in Project Management: Perceptions of Responsibility." Sustainability Integration for Effective Project Management, 2013, pp. 279-287. https://doi.org/10.4018/978-1-4666-4177-8.ch017

[17] M. Eid, "How Can Sustainable Development Redefine Project Management Processes?" Sustainability Integration for Effective Project Management, p. 76, 2013

https://doi.org/10.4018/978-1-4666-4177-8.ch005.

[18] WANG, NANNAN, et al. "Critical factors for sustainable project management in public projects." International Association for Management of Technology-IAMOT, 2015.

[19] Marcelino-Sádaba, Sara, Luis Felipe González-Jaen, and Amaya Pérez-Ezcurdia. "Using project management as a way to sustainability. From a comprehensive review to a framework definition." Journal of cleaner production 99, 2015, pp. $1-16$.

https://doi.org/10.1016/j.jclepro.2015.03.020

[20] Martens, Mauro L., and Marly M. Carvalho. "Key factors of sustainability in project management context: A survey exploring the project managers' perspective." International Journal of Project Management, 2016. https://doi.org/10.1016/j.ijproman.2016.04.004

[21] Shen, Li Yin, Jian Li Hao, Vivian Wing- Yan Tam, and Hong Yao"A checklist for assessing sustainability performance of construction projects." Journal of civil engineering and management 13.4, 2007, pp. 273-281.

[22] Khalili-Damghani, Kaveh, and SoheilSadi-Nezhad. "A decision support system for fuzzy multi-objective multi-period sustainable project selection." Computers \& Industrial Engineering 64.4, 2013, 1045-1060.

[23] Heravi, Gholamreza, MedyaFathi, and Shiva Faeghi. "Evaluation of sustainability indicators of industrial buildings focused on petrochemical projects." Journal of Cleaner Production 109, 2015, pp. 92-107.

https://doi.org/10.1016/j.jclepro.2015.06.133

[24] Sánchez, Marisa Analía. "Integrating sustainability issues into project management." Journal of Cleaner Production 96, 2015, pp. 319-330. https://doi.org/10.1016/j.jclepro.2013.12.087

[25] Shen, Liyin, Vivian WY Tam, Lin Gan, Kunhui Ye, and Zongnan Zhao. "Improving Sustainability Performance for Public-Private-Partnership (PPP) Projects." Sustainability 8.3, 2016, p. 289. 
[26] Siew, Renard YJ, Maria CA Balatbat, and David G. Carmichael. "Measuring project sustainability maturity level-a fuzzy-based approach." International Journal of Sustainable Development 19.1, 2016, pp. 76-100.

[27] Martens, Mauro Luiz, MarlyMonteiro De Carvalho, and Cristina Dai Prá Martens. Sustainability and success in project management: A forum with academic experts- 25th International Association for Management of Technology Conference, Proceedings: Technology - Future Thinking, 2016, pp. 1347-1360.

[28] Ugwu O.O, Haupt T.C, Key Performance Indicators and Assessment Methods forInfrastructure sustainability - a South African construction industry perspective, Building and Environment, 2007, pp. 665-680

https://doi.org/10.1016/j.buildenv.2005.10.018

[29] Eskerod, Pernille, and Martina Huemann. "Sustainable development and project stakeholder management: what standards say?" International Journal of Managing Projects in Business 6.1, 2013, p. 36-50. 